\title{
Penyuluhan Kewirausahaan Bagi Anggota Kelompok Karang Taruna Di Kelurahan Malaka
} Sari, Duren Sawit

Rahmi ${ }^{1,}$ Dedi Purwana ${ }^{2,}$ Shandy Aditya ${ }^{3}$.

${ }^{1}$ Universitas Negeri Jakarta

${ }^{2}$ Universitas Negeri Jakarta

${ }^{3}$ Universitas Negeri Jakarta

\section{ARTICLE INFO}

Article history:

Received: May 2019

Accepted: June 2019

Published: $1^{\text {st }}$ Juli 2019
Keywords:

Entrepreneurship, Karang Taruna, Remaja, Wirausaha

\section{$A B S T R A C T$}

Getting a job has been more difficult nowadays due to the scarcity of job opportunities. The number of available manpower is much higher than the job vacancies. The incompatibility of expertise and difficulties to meet company's requirement with suitable job seeker also increase the unemployment rate. This program is performed to stimulate young people to think creative innovative and eventually encourage them to start their own business as solution to the problem. The method used is explanation, experiences sharing, question and answer, discussion, and business plan presentation. Based on these activities, not only participants' knowledge about entrepreneurship increases, but also their ability to create a product or business systematically is trained. Furthermore, capital issue is solved by providing alternatives of business form such as dropshipper, franchising, or joint venture. Last but not least, a message group is formed as a media to discuss, consult, and encourage each other to start a business or participate in business plan competition.

\section{How to cite:}

* Corresponding Author.

Dpurwana@unj.ac.id (Dedi Purwana)

Rahmi@unj.ac.id (Rahmi)
ISSN

2580-4332 (online)

DOI:doi.org/10.21009/JPMM.003.1.11 


\section{PENDAHULUAN}

\section{Analisis Situasi}

Masalah pengangguran merupakan masalah klasik di Indonesia. Laju pertumbuhan tenaga kerja yang lebih tinggi dibanding laju pertumbuhan lapangan kerja, ketidaksesuaian keahlian tenaga kerja dan kebutuhan penyedia kerja, serta sulitnya mempertemukan pencari kerja dan penyedia kerja dianggap sebagai salah satu faktor penyebabnya (Hendriyana, 2010).

Pemerintah pun berusaha mengatasi permasalahan pengangguran ini dengan menciptakan lapangan pekerjaan melalui program strategis (PresidenRI, 2017), di antaranya; mendorong pembangunan infrastruktur dengan menyediakan anggaran melalui APBN, BUMN, dan swasta; menumbuhkan investasi dengan cara memperbaiki iklim investasi melalui penyederhanaan perizinan dan penyediaan sarana investasi; mendorong pendidikan vokasional yang menghasilkan tenaga kerja dengan keahlian tertentu yang sesuai dengan permintaan industri; mengalokasikan dana desa yang digunakan untuk program pemberdayaan masyarakat dan pembangunan sarana/prasarana di pedesaan; meluncurkan situs www.joinkandidat.com sebagai hasil kerjasama antara Kementerian Tenaga Kerja dengan kelompok musik Slank yang berguna untuk mempertemukan perusahaan dan pencari kerja yang fokus pada pencari kerja menengah ke bawah. Di situs ini, pencari kerja cukup mengisi formulir aplikasi tanpa harus mengirim $\mathrm{CV}$, lamaran, atau foto ke masing-masing perusahaan.
Tingkat ketenagakerjaan di Indonesia digambarkan ke dalam infografis Gambar 1. Menurut data yang dilansir oleh Badan Pusat Statistik (BPS), terjadi kenaikan angka pengangguran di Indonesia dari Agustus 2016 hingga Agustus 2017 sebesar 10 ribu orang sehingga menjadi 7,04 juta orang dengan tingkat pengangguran di kota lebih tinggi dari tingkat pengangguran di desa (Badan Pusat Statistik, 2017). Kenaikan angka pengangguran ini diperkirakan disebabkan oleh meningkatnya jumlah angkatan kerja (penduduk usia produktif 15-64 tahun yang sudah bekerja atau sedang mencari pekerjaan) di Indonesia sebesar 2,62 juta orang, atau dari 125,44 juta orang di Agustus 2016 menjadi 128,06 juta orang di Agustus 2017.

Kenaikan jumlah angkatan kerja ini juga diimbangi oleh Tingkat Partisipasi Angkatan Kerja (TPAK), yaitu persentase perbandingan jumlah angkatan kerja dibandingkan jumlah seluruh penduduk usia kerja, sebesar 0,33 poin, sementara Tingkat Pengangguran Terbuka (TPT), yakni persentase jumlah pengangguran atau pencari kerja dibandingkan dengan jumlah angkatan kerja, turun sebesar 0,11 poin menjadi 5,50\% (Badan Pusat Statistik, 2017).

Semakin tinggi TPT berarti semakin banyak angkatan kerja yang tidak terserap oleh pasar kerja. Kepala BPS Kecuk Suhariyanto menyampaikan bahwa jumlah angkatan kerja mencapai 3 juta orang per tahun sehingga komposisi pekerja dan penganggurannya pun akan terus naik, namun yang paling pent- 
ing adalah turunnya persentase TPT (Julianto, 2017).

Sementara jika dilihat dari tingkat pendidikan, mayoritas TPT berasal dari Sekolah Menengah Kejuruan (SMK), yaitu sebesar 11,41\%. TPT selanjutnya berasal dari tingkat pendidikan Sekolah Menengah Atas (SMA) sebesar $8,29 \%$. TPT terendah sebesar 2,62\% adalah penduduk dengan tingkat pendidikan sekolah dasar (SD) ke bawah. Suhariyanto menyampaikan bahwa TPT yang paling rendah berasal dari tingkat pendidikan SD ke bawah karena mereka tidak punya pilihan sehingga akan menjalani pekerjaan apapun (Basuki, 2017).

Melihat kondisi seperti ini, sudah se- layaknya masyarakat Indonesia berpikir secara kreatif dan inovatif keluar dari zona nyaman mereka dan memulai usaha sendiri. Saat ini jumlah wirausaha diperkirakan sebanyak 3\% dari jumlah penduduk, jauh lebih sedikit jika dibandingkan dengan Malaysia dengan 5\%, Singapura 7\%, atau Jepang 11\% (Prahara, 2017).

Menteri Perencanaan Pembangunan Nasional Bambang Brodjonegoro menyampaikan bahwa salah satu usaha untuk menurunkan ketimpangan ekonomi adalah dengan perluasan kesempatan kerja yang berkualitas dan wirausaha (Prahara, 2017). Pemerintah melalui Kementerian Komunikasi dan Informatika telah mencanangkan Gerakan

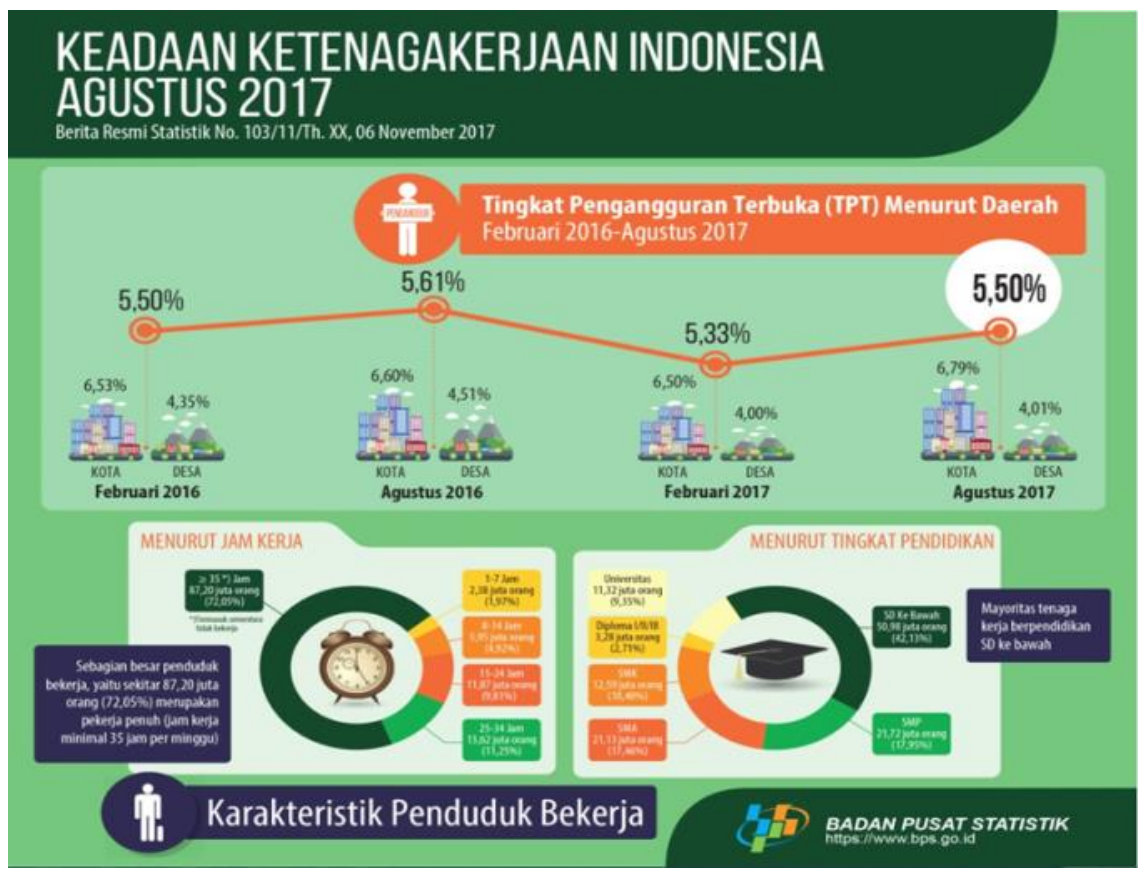

Gambar 1

Keadaan Ketenagakerjaan Indonesia Agustus 2017

Sumber: https://www.bps.go.id/pressrelease/2017/11/06/1377/agustus-2017--tingkat

-pengangguran-terbuka--tpt--sebesar-5-50-persen.html 
Nasional 1.000 Usaha Rintisan yang mendukung ekonomi kerakyatan.

Usaha rintisan (start up) mulai marak dalam beberapa tahun terakhir, terutama dari generasi muda. Usaha rintisan diharapkan mampu menyerap tenaga kerja seiring dengan pertumbuhan bisnisnya dan membantu berjalannya perekonomian dengan aliran suntikan dana. Potensi remaja sebagai pemilik dan pelaku usaha rintisan harus mendapatkan dukungan juga dengan diberikan wawasan dan pemahaman mengenai kewirausahaan, maka dari itu tim Pengabdian pada Masyarakat memiliki ide untuk menyelenggarakan kegiatan "Penyuluhan Kewirausahaan bagi Anggota Kelompok Karang Taruna di Kelurahan Malaka Sari, Duren Sawit".

\section{Identifikasi dan Perumusan Masalah}

Berdasarkan uraian di atas, maka dapat diidentifikasi terdapat permasalahan sebagai berikut:

1. Tingginya tingkat pengangguran dan terbatasnya lapangan pekerjaan.

2. Dibutuhkan alternatif solusi yang kreatif dan inovatif, salah satunya dengan berwirausaha.

3. Masih sedikit pelaku wirausaha di Indonesia dibandingkan dengan negaranegara lain di Asia.

4. Usaha rintisan (start up) di Indonesia mulai berkembang, termasuk oleh pelaku wirausaha remaja.

Identifikasi masalah yang telah disebutkan di atas membawa kita ke perumusan masalah berikut:

1. Sejauh mana pengetahuan dan pemaham- an remaja mengenai peluang dan tantangan berwirausaha?

2. Alternatif bisnis apa saja yang minim modal dan dapat segera direalisasikan?

\section{Tujuan Kegiatan}

Kegiatan Pengabdian pada Masyarakat ini bertujuan untuk:

1. Memberikan pengetahuan dan pemahaman kepada remaja Karang Taruna mengenai peluang dan tantangan berwirausaha;

2. Memberikan ide alternatif bisnis apa saja yang minim modal dan dapat segera direalisasikan.

\section{Manfaat Kegiatan}

Manfaat yang diperoleh dari kegiatan ini adalah:

A. Peserta

1. Remaja Karang Taruna yang menjadi peserta menjadi tahu dan paham akan mengenai peluang dan tantangan berwirausaha;

2. Remaja Karang Taruna yang menjadi peserta dapat terinspirasi dan termotivasi untuk berwirausaha.

B. Tim Pengabdian pada Masyarakat

1. Memberikan kontribusi pengetahuan dan pengalaman kepada masyarakat khususnya remaja Karang Taruna sesuai dengan kompetensi yang dimiliki oleh instruktur;

2. Memperbarui ilmu dan wawasan mengenai kewirausahaan. 


\section{KAJIAN TEORETIK}

\section{Pengertian Karang Taruna}

Peraturan Menteri Sosial Republik Indonesia No. 77/HUK/2010 tentang Pedoman Dasar Karang Taruna menyatakan Karang Taruna adalah organisasi sosial kemasyarakatan sebagai wadah dan sarana pengembangan setiap anggota masyarakat yang tumbuh dan berkembang atas dasar kesadaran dan tanggung jawab sosial dari, oleh, dan untuk masyarakat terutama generasi muda di wilayah desa/ kelurahan terutama bergerak di bidang usaha kesejahteraan sosial (Suprayoga, Iswoyo, \& Syahrial, 2016).

Karang Taruna menitikberatkan pada kesadaran dan tanggung jawab sosial dalam pelaksanaan pembangunan sehingga dapat mewujudkan dengan baik kesejahteraan sosial yang dapat dinikmati oleh seluruh masyarakat. Dalam konteks ini, Karang Taruna sebagai organisasi penggerak pembangunan berusaha mendukung upaya pemerintah untuk mengatasi masalah tingginya tingkat pengangguran dengan meningkatkan wawasan, pemahaman, dan keterampilan pemuda dalam berwirausaha.

\section{Wirausaha}

Kewirausahaan adalah perilaku terencana terkait dengan minat yang dimiliki oleh seseorang (Mopangga, 2014). Wirausahawan diartikan sebagai orang yang memiliki kemampuan untuk mendapatkan peluang keberhasilan, yang mungkin saja didapat dari pendidikan tinggi dan keterampilan, atau mungkin saja seorang buta huruf yang memiliki keahlian di bidangnya yang diperoleh dari pengalaman hidup dan bukan pendidikan formal pada umumnya (Sembiring, 2009). Sementara itu Suharyadi et.al (2007) mendefinisikan wirausahawan sebagai seseorang yang menciptakan suatu usaha atau bisnis yang dihadapkan dengan risiko dan ketidakpastian untuk memperoleh keuntungan dan mengembangkan bisnis dengan cara mengenali kesempatan dan memanfaatkan sumber daya yang diperlukan.

Meredith dalam Suharyadi et.al (2007) mengemukakan ciri-ciri wirausahawan sebagai berikut:

1. Percaya diri untuk memulai, melakukan, dan menyelesaikan tugas atau pekerjaan yang dihadapi;

2. Berorientasi pada tugas dan hasil;

3. Berani mengambil risiko;

4. Kepemimpinan yaitu menjadi teladan, berpikir positif, tidak anti kritik, dan memiliki kecakapan dalam bergaul;

5. Orisinal yaitu unik, inovatif, dan kreatif; 6. Berorientasi pada masa depan.

Priyanto dalam Mopangga (2014) menyampaikan bahwa jiwa wirausaha seseorang dipengaruhi oleh beberapa faktor, yaitu:

- $\quad$ Faktor internal, yaitu sifat personal, sikap, kemauan, dan kemampuan yang memberi kekuatan individu untuk berwirausaha;

- Faktor eksternal seperti lingkungan keluarga, lingkungan dunia usaha, lingkungan fisik, dan lingkungan sosial ekonomi.

Banyak manfaat yang diperoleh 
dengan menjadi wirausahawan. Selain kemampuan mengatur waktu yang tidak terbatasi dalam jam kantor serta dapat menentukan aturan sendiri yang sesuai dengan karakter diri dan pekerjaan, beberapa keuntungan lain yang didapat dengan menjadi wirausahawan antara lain (Suharyadi, Nugroho, Purwanto, \& Faturohman, 2007):

1. Mempunyai kebebasan mencapai tujuan yang dikehendaki;

2. Mempunyai kesempatan untuk menunjukkan kemampuan dan potensi diri secara penuh;

3. Memperoleh manfaat dan laba yang maksimal;

4. Terbuka kesempatan untuk melakukan perubahan;

5. Terbuka peluang untuk membantu masyarakat dalam menciptakan lapangan kerja;

6. Terbuka peluang untuk berperan dalam masyarakat dan mendapatkan pengakuan atas usaha sendiri.

\section{MATERI DAN METODE}

\section{Kerangka Pemecahan Masalah}

Kegiatan penyuluhan kewirausahaan ini memiliki rangka atau tahapan kegiatan sebagai berikut:

\section{A. Analisis Kebutuhan}

Berdasarkan latar belakang yang telah dipaparkan pada bagian analisis situasi, serta kajian yang dilakukan oleh tim Pengabdian pada Masyarakat, maka dirasa dibutuhkan pelaksanaan program kegiatan ini dengan pertimbangan:
1) Terbatasnya ketersediaan lapangan pekerjaan sehingga mengakibatkan masyarakat harus berusaha secara lebih kreatif dan inovatif, salah satunya dengan berwirausaha.

2) Kurangnya pengetahuan dan pemahaman tentang berwirausaha di masyarakat, termasuk di antaranya remaja-remaja yang tergabung dalam Karang Taruna, padahal mereka memiliki potensi yang sangat besar;

3) Kurangnya pengetahuan dan pemahaman mengenai alternatif usaha yang minim modal.

\section{B. Rancangan Instruksional}

Rancangan instruksional disusun dengan mempertimbangkan aspek-aspek berikut:

1) Isi materi program kegiatan yang relevan dengan pengetahuan dan kebutuhan peserta. Tim Pengabdian pada Masyarakat ini telah memetakan kebutuhan materi keseluruhan bagi remaja Karang Taruna yang dibagi dalam dua segmen materi kegiatan, yaitu pemaparan materi kewirausahaan yang dilanjutkan dengan diskusi kelompok yang akan dijelaskan lebih lanjut pada bagian materi kegiatan.

2) Latar belakang peserta kegiatan seperti seperti tingkat pendidikan, pekerjaan, usia, jenis kelamin dan sebagainya.

3) Jenis usaha yang tertarik untuk digeluti atau mungkin sudah sedang digeluti. 


\section{Tahap Pengembangan}

Pada kegiatan ini, tim Pengabdian pada Masyarakat berupaya mengembangkan kegiatan baik dalam hal penyampaian materi kegiatan, diskusi kelompok, maupun tanya jawab atas materi yang disampaikan. Selain itu, setelah selesai acara, dibentuklah grup Whatsapp (aplikasi pesan) yang ditujukan untuk pemantauan, konsultasi, dan pembinaan lebih lanjut.

\section{Realisasi Pemecahan Masalah}

Pelaksanaan kegiatan Pengabdian pada Masyarakat ini adalah hari Minggu tanggal 7 Oktober 2018 di gedung Sony Sugema Colege. Gedung ini berlokasi di Jl. Malaka Raya no. 71 dan 75, RT.03/RW.06, Kelurahan Malaka Sari, Kecamatan Duren Sawit, Jakarta Timur. Kegiatan dilaksanakan selama empat jam, dimulai dari pukul 09.00 dan selesai pada pukul 13.00 WIB.

\section{Khalayak Sasaran}

Peserta yang hadir dalam kegiatan ini sebanyak 19 orang yaitu anggota Karang Taruna di Kelurahan Malaka Sari, Kecamatan Duren Sawit, Jakarta Timur, namun hanya 17 orang yang mengikuti kegiatan hingga selesai. Peserta terdiri dari 11 orang perempuan dan 8 orang laki-laki dengan rentang usia 16 hingga 42 tahun. Peserta yang berusia 42 tahun merupakan koordinator Karang Taruna di Kelurahan Malaka Sari tersebut. Sebagian besar peserta berprofesi sebagai pelajar atau mahasiswa.

Kegiatan penyuluhan kewirausahaan dibiayai oleh Universitas Negeri Jakarta yang dilaksanakan sebagai salah satu pengamalan Tridharma Perguruan Tinggi, yakni pengaja- ran, penelitian, serta pengabdian kepada masyarakat. Kegiatan ini juga berkaitan dengan instansi lainnya misalnya pemerintah setempat mulai dari Kelurahan sampat tingkat Rukun Warga yang memberikan perizinan untuk kegiatan ini. Dalam kegiatan ini, tim Pengabdian pada Masyarakat bekerja sama dengan pihak Sony Sugema College sebagai penyedia lokasi pelatihan.

\section{Metode Kegiatan}

Dalam kegiatan ini, metode yang digunakan adalah metode penjelasan, sharing, tanya jawab, diskusi kelompok. Metode kegiatan yang digunakan pada program kegiatan ini diharapkan dapat memberikan kemudahan dan pemahaman kepada peserta kegiatan.

Pada metode penjelasan, instruktur menyampaikan materi mengenai kewirausahaan melalui slide presentasi power point yang ditampilkan menggunakan proyektor LCD. Materi yang disampaikan juga dikemas dalam bentuk modul kegiatan yang dibagikan ke peserta beserta alat tulis untuk memudahkan peserta mencatat hal-hal penting sepanjang kegiatan. Materi yang disusun oleh instruktur adalah berdasarkan pengalaman atau sharing, teori-teori, serta tips dan trik mengenai memulai usaha mandiri.

Pada metode diskusi kelompok, peserta diminta untuk membentuk kelompokkelompok kecil yang terdiri dari empat hingga lima orang. Di dalam kelompok ini, mereka diarahkan untuk saling bertukar pikiran 
mengenai peluang wirausaha yang dapat dicoba.

\section{Materi Kegiatan dan Instruktur}

Materi dibuka dengan perkenalan instruktur. Di sini instruktur juga menjelaskan usaha-usaha wirausaha yang digelutinya yang mencakup berbagai bidang dari mulai makanan, pakaian, cukur rambut, hingga dokumentasi (foto, video, drone). Selain itu disampaikan juga contoh-contoh sukses wirausaha seperti Kebab Turki Baba Rafi, Go-Jek, serta media sosial fenomenal Facebook.

Setelah itu dipaparkan alasan-alasan mengapa seseorang harus menjadi wirausaha, yakni manfaat dan risiko menjadi seorang wirausaha. Selain itu disampaikan juga hal-hal yang dibutuhkan dalam berwirausaha seperti penemuan ide dan pengembangannya (dimulai dari ide yang sederhana sebagai solusi untuk masalah yang ditemui sehari-hari, melakukan penelitian, bertukar pikiran dengan siapapun, mengembangkan ide dan melaksanakannya dari yang paling mudah), membuat rancangan bisnis (deskripsi usaha, produk, pemasaran dan penjualan, keuangan), membangun jaringan (networking), serta sumber modal (minim modal, modal pribadi, modal keluarga atau teman, pinjaman bank, joint venture, crowd funding). Dijelaskan juga kepada peserta mengenai alternatif jenis usaha waralaba (franchise) dibandingkan dengan usaha sendiri dilihat dari sisi model kepemilikan, biaya, merek, operasional, dan tingkat keberhasilan dari masing-masing pilihan.

Kesalahan umum yang sering dilakukan oleh para wirausahawan adalah melakukan usaha hanya sekedar meniru atau ikut-ikutan orang lain, tidak adanya perencanaan, biaya yang lebih besar daripada pemasukan, malas memeriksa laporan keuangan, kesuksesan yang terlalu dini, serta terlalu banyak hal yang ingin dikerjakan sehing-

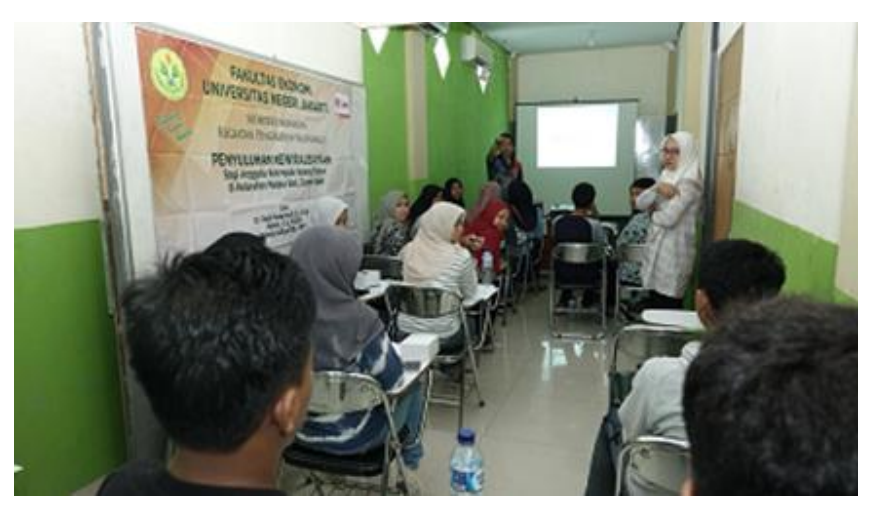

Gambar 2

Pemaparan Materi 
ga tidak fokus. Di sisi lain, tantangan menjadi sseorang wirausaha pun tidak mudah. Mereka mungkin menghadapi kekurangan modal, berbagai perubahan yang mesti diadaptasi seperti teknologi, serta ekonomi secara global.

Setelah paparan selesai, peserta diminta untuk membuat kelompok-kelompok kecil. Tiap kelompok terdiri dari empat hingga lima orang. Tiap kelompok berdiskusi untuk mengemukakan suatu ide usaha dan membuat perencanaan atas idenya itu. Ide dan perencanaan ini kemudian dipresentasikan untuk mendapatkan tanggapan dari instruktur serta seluruh peserta.

\section{HASIL DAN PEMBAHASAN}

Peserta yang hadir dalam kegiatan ini sebanyak 19 orang yaitu anggota Karang Taruna di Kelurahan Malaka Sari, Kecamatan Duren Sawit, Jakarta Timur, namun hanya 17 orang yang mengikuti kegiatan hingga selesai. Peserta terdiri dari 11 orang perempuan dan 8 orang laki-laki dengan rentang usia 16 hingga 42 tahun. Peserta yang berusia 42 tahun merupakan koordinator Karang Taruna di Kelurahan Malaka Sari tersebut. Sebagian besar peserta berprofesi sebagai pelajar atau mahasiswa.

Peserta diminta untuk mengisi kuesioner yang berguna untuk mendata informasi diri, serta informasi mengenai usaha yang sudah atau ingin dimilikinya. Dari kuesioner tersebut, ada beberapa kesimpulan yang dapat ditarik yang akan dipaparkan di bawah ini. Sebanyak 4 dari 17 orang atau sebesar 24\% sudah memiliki usaha sendiri. Usaha ini bergerak di bidang makanan/ minuman, pulsa, serta online shop. Meski demikian, sebanyak 5 orang atau $29 \%$ mengaku ingin memiliki usaha sendiri di masa yang akan dating dan sisanya sebanyak 12 orang atau $71 \%$ bahkan mengaku sangat

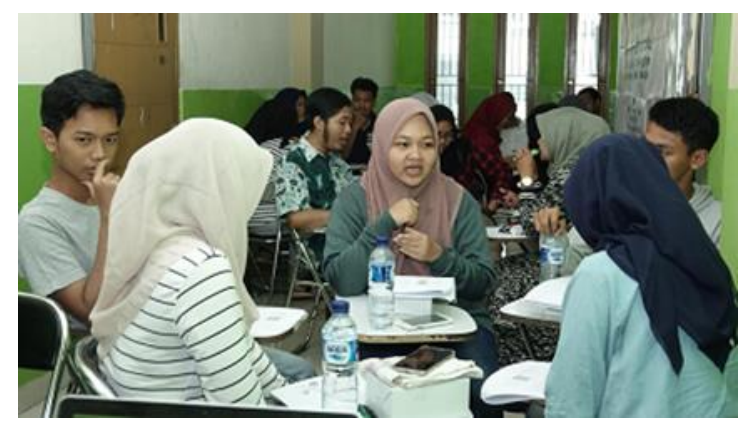

Gambar 3

Diskusi Kelompok 
ingin memiliki usaha sendiri. Bidang usaha yang ingin mereka miliki sangat beragam, mulai dari makanan/minuman, sepatu, otomotif, pakaian, tanaman hias, peternakan ikan, kosmetik, hingga jasa desain.

Peserta juga ditanyakan mengenai rencana sumber modal usaha, apakah berasal dari modal pribadi, keluarga, pinjaman bank, investor, atau dari kompetisi. Hasil jawaban dari para peserta terdapat pada table 1 .

Dari jawaban di atas, dapat kita simpulkan bahwa sebagian besar peserta atau sebanyak $77 \%$ berencana untuk menggunakan modal pribadi sebagai sumber modal. Alternatif kedua adalah modal dari keluarga. Sementara itu, pinjaman bank merupakan pilihan terakhir bagi mayoritas peserta, yaitu sebanyak 11 orang atau $65 \%$.

Setelah diberikan materi dasar mengenai kewirausahaan, peserta secara berkelompok diminta untuk membuat sebuah proposal usaha. Mereka dituntut untuk berpikir kreatif dan inovatif. Peserta diajarkan langkah-langkah untuk membuat suatu usaha. Langkah pertama adalah menemukan masalah. Masalah ini bisa berada di sekitar mereka ataupun mengacu pada tujuh belas tujuan pembangunan berkelanjutan (17 Sustainable Development Goals) dari PBB yang dipetakan pada gambar 5 .

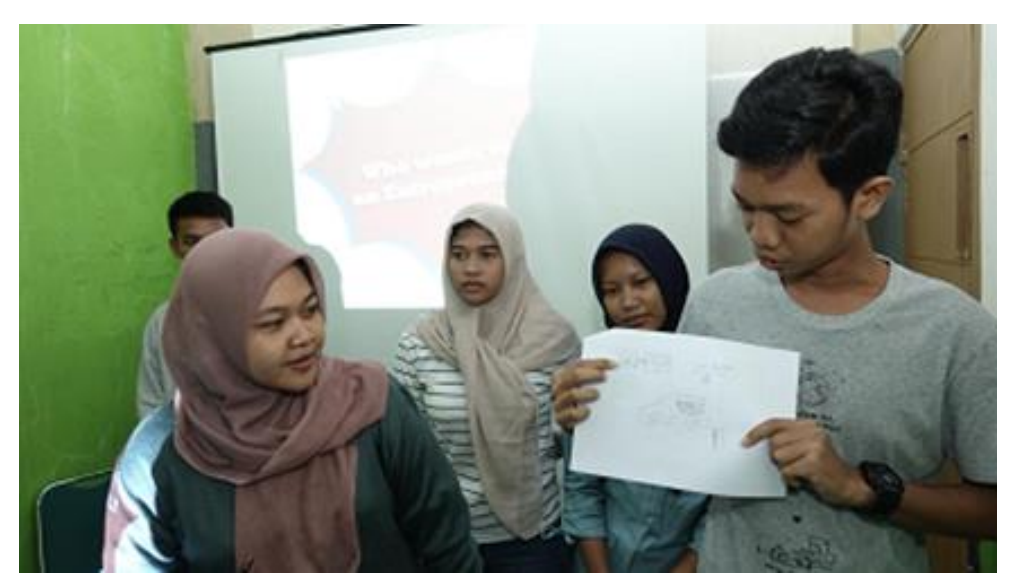

Gambar 4

Presentasi Rencana Usaha 
Dari semua daftar masalah yang ditemukan, pilihlah satu masalah atau rangkum semua masalah menjadi satu masalah untuk kemudian dicari kebutuhan untuk penyelesaiannya. Setelah tau apa saja yang dibutuhkan, buat alternatif solusi dari kebutuhan tersebut sesuai dengan kreativitas masing -masing. Dari alternatif solusi ini, mereka harus dapat membuat manfaat apa saja yang diberikan dari tiap solusi untuk mengatasi permasalahan yang ada. Pemikiran mengenai solusi ini kemudian dituangkan secara tertulis melalui rancangan usaha sehingga ada wujud konkret dari pemikiran ini. Secara singkat, langkah-langkah tadi terdiri atas:

a. Define problem;

b. The needs to solve the problem;

c. The solution from the needs;

d. The feature in the solution;

e. Prototype design.

\section{KESIMPULAN DAN SARAN}

Pengangguran merupakan masalah serius di Indonesia. Laju pertumbuhan tenaga kerja yang lebih tinggi dibanding laju pertumbuhan lapangan kerja, ketidaksesuaian keahl-

\begin{tabular}{|c|c|c|c|c|c|c|}
\hline & \multicolumn{5}{|c|}{$\begin{array}{c}\text { Pilihan Peserta } \\
\text { Urutan ke - }\end{array}$} & \\
\hline $\begin{array}{l}\text { Sumber } \\
\text { Modal }\end{array}$ & 1 & 2 & 3 & 4 & 5 & \\
\hline $\begin{array}{l}\text { Modal } \\
\text { pribadi }\end{array}$ & 13 & 2 & 0 & 1 & 1 & 17 \\
\hline Keluarga & 2 & 10 & 3 & 1 & 1 & 17 \\
\hline $\begin{array}{l}\text { Pinjaman } \\
\text { Bank }\end{array}$ & 1 & 0 & 2 & 3 & 11 & 17 \\
\hline Investor & 0 & 5 & 6 & 6 & 0 & 17 \\
\hline Kompetisi & 1 & 0 & 6 & 6 & 4 & 17 \\
\hline & 17 & 17 & 17 & 17 & 17 & \\
\hline
\end{tabular}

Tabel 1

Rencana Sumber Modal Usaha 
ian tenaga kerja dan kebutuhan penyedia kerja, serta sulitnya mempertemukan pencari kerja dan penyedia kerja dianggap sebagai salah satu faktor penyebabnya (Hendriyana, 2010).

Meskipun pemerintah telah melakukan berbagai upaya untuk mengatasi masalah ini, namun tingkat pengangguran di Indonesia masih saja tinggi. Kondisi ini menuntut masyarakat Indonesia untuk berpikir secara kreatif dan inovatif dengan memulai usaha sendiri atau berwirausaha.

Tingkat wirausaha di Indonesia saat ini diperkirakan sebanyak $3 \%$ dari jumlah penduduk, jauh lebih sedikit jika dibandingkan dengan Malaysia dengan 5\%, Singapura 7\%, atau Jepang 11\% (Prahara, 2017). Usaha rinti- san (start up) mulai marak dalam beberapa tahun terakhir, terutama dari generasi muda. Remaja yang memiliki potensi sebagai pemilik dan pelaku usaha rintisan harus mendapatkan dukungan. Dukungan ini dapat berupa pemberian wawasan dan pemahaman mengenai kewirausahaan. Maka dari itu, kegiatan penyuluhan kewirausahaan ini mengambil anggota Karang Taruna sebagai target peserta.

Kegiatan Pengabdian pada Masyarakat ini memberikan wawasan tentang kisah sukses berwirausaha, manfaat dan risiko menjadi wirausahawan, pengembangan ide, pembuatan rencana bisnis, pembangunan jaringan,
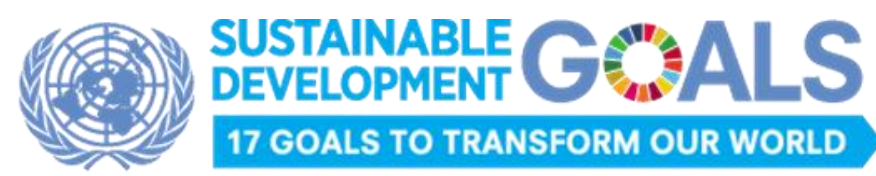

17 GOALS TO TRANSFORM OUR WORLD
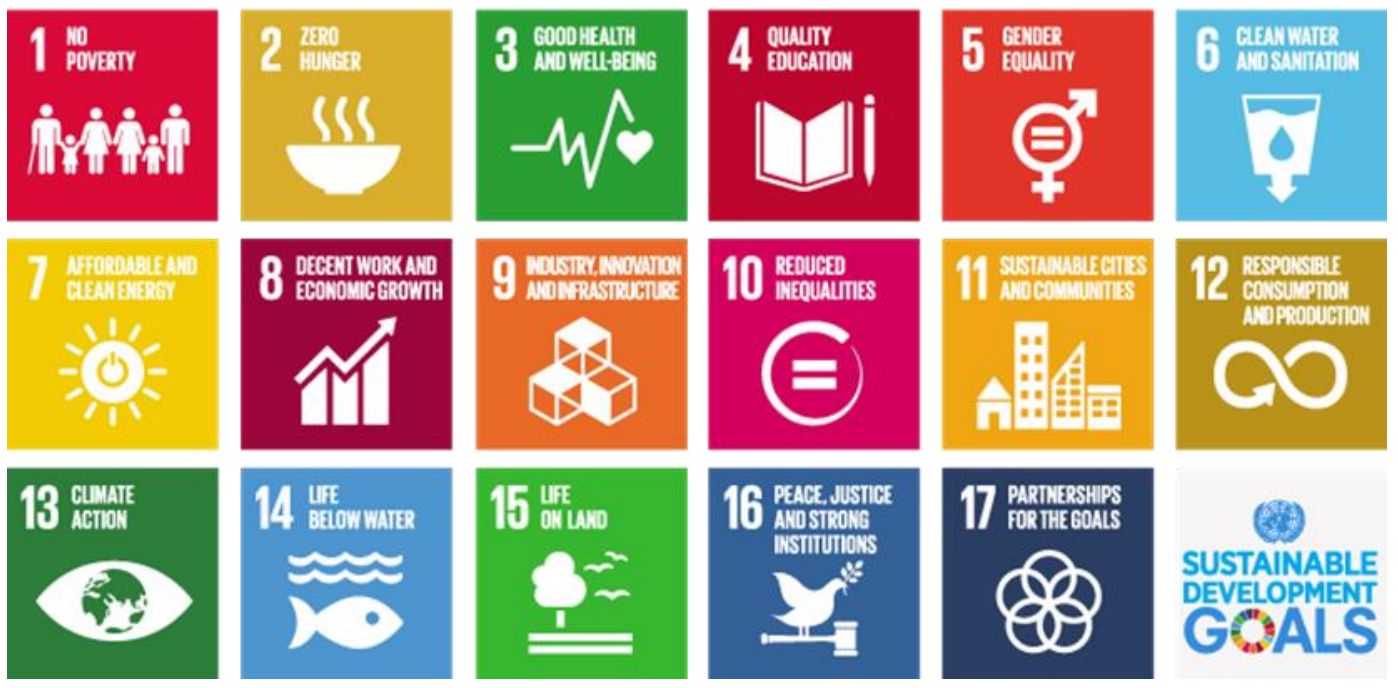

SUSTAINABLE DEVELOPMENT GOALS

Gambar 5

Sustainable Development Goals - United Nations 
sumber modal, alternatif tipe bisnis, serta kesalahan dan tantangan yang lazim dilakukan oleh para wirausahawan. Hal yang sering dikeluhkan sebelum memulai berwirausaha adalah keterbatasan modal, sehingga di sini dijelaskan pula bahwa ada tipe-tipe usaha yang minim modal, misalnya menjadi perantara, dropshipper, atau berjualan dengan sistem Purchase Order (PO). Untuk menurunkan risiko usaha, seseorang dapat pula menggunakan bentuk-bentuk usaha yang cenderung lebih aman seperti franchise dan joint venture. Kegiatan penyuluhan kewirausahaan ini juga mengajarkan tentang langkah-langkah penyusunan usaha secara konkret.

Dari kegiatan Pengabdian pada Masyarakat ini, dapat kita simpulkan bahwa secara umum generasi muda memiliki ketertarikan tinggi untuk berwirausaha namun tidak memiliki panduan yang jelas dalam pelaksanaannya. Keterbatasan modal sering menjadi alasan yang menghambat dari awal penyusunan rencana bisnis, padahal keadaan ini dapat diatasi dengan beberapa cara. Penemuan masalah yang sederhana juga dapat menjadi salah satu cara yang efektif untuk mengawali sebuah rencana bisnis.

Selain itu, seseorang akan lebih bereaksi lebih optimal terhadap simulasi (workshop) dibandingkan apabila hanya dijelaskan secara teoretis. Mereka memahami langkah-langkah untuk membuat suatu usaha lalu mencoba untuk mengaplikasikan pengetahuan baru mereka tersebut secara langsung melalui pembuatan rencana usaha secara kelompok. Rencana ini kemudian dipresentasikan untuk mendapatkan umpan balik sehingga masing-masing dapat melakukan koreksi serta lebih memahami mengenai poin-poin penting yang dibutuhkan dalam berwirausaha.

Kesertaan dalam kompetisi rencana bisnis atau rencana rintisan usaha (start-up plan) juga dapat melatih keahlian seseorang dan menajamkan insting bisnisnya sehingga dapat menciptakan usaha yang kreatif, inovatif, menguntungkan, dan berkelanjutan.

Saran yang dapat disampaikan oleh tim Pengabdian pada Masyarakat adalah pentingnya keberlanjutan komunikasi setelah diadakannya penyuluhan atau pelatihan. Hal ini dicoba untuk diwujudkan oleh tim Pengabdian pada Masyarakat dengan cara dibuat komunitas atau grup binaan wirausaha muda melalui grup Whatsapp. Melalui media ini mereka dapat saling berkomunikasi, berdiskusi membagi ide-ide, berkonsultasi, serta saling mendukung untuk kesertaan dalam kompetisikompetisi start up.

\section{DAFTAR PUSTAKA}

(2017, November 6). Retrieved February 21, 2018, from Badan Pusat Statistik: https://www.bps.go.id/ pressrelease/2017/11/06/1377/agustus2017--tingkat-pengangguran-terbuka-tpt--sebesar-5-50-persen.html

(2017, 11 6). Retrieved 2 21, 2018, from Badan Pusat Statistik: https:// www.bps.go.id/ pressrelease/2017/11/06/1377/agustus2017--tingkat-pengangguran-terbuka-- 
tpt--sebesar-5-50-persen.html

Basuki, C. (2017, November 6). Retrieved February 21, 2018, from AntaraNews.com: https:// www.antaranews.com/berita/663248/ tingkat-pengangguran-terbuka-agustus55-persen-di-kota-lebih-tinggi-dari-didesa

Hendriyana, A. (2010, October 29). Retrieved February 22, 2018, from Universitas Padjadjaran: http://news.unpad.ac.id/? $p=36576$

Julianto, P. A. (2017, November 6). Retrieved February 21, 2018, from Kompas.com: http://ekonomi.kompas.com/ $\mathrm{read} / 2017 / 11 / 06 / 153940126 /$ agustus2017-jumlah-pengangguran-naik-menjadi -704-juta-orang

Mopangga, H. (2014). Faktor Determinan Minat Wirausaha Mahasiswa Fakultas Ekonomi dan Bisnis Universitas Negeri Gorontalo. Trikonomika , 78-90.

Prahara, H. (2017, September 30). Ekonomi Digital, Masa Depan Kewirausahaan Indonesia. Retrieved February 22, 2018, from Kompas.com: http:// ekonomi.kompas.com/ $\operatorname{read} / 2017 / 09 / 30 / 111300626 /$ ekonomidigital-masa-depan-kewirausahaanindonesia

PresidenRI. (2017, May 18). Retrieved February 22, 2018, from www.presidenri.go.id: http://presidenri.go.id/program-prioritas2/upaya-nyata-pemerintah-membukalapangan-kerja.html

Sembiring, S. (2009). Penyuluhan
Kewirausahaan kepada Generasi Muda dan Pengusaha dalam rangka Meningkatkan Kesejahteraan Masyarakat di Kecamatan Kiara Condong Kota Bandung.

Suharyadi, Nugroho, A., Purwanto, S. K., \& Faturohman, M. (2007). Kewirausahaan - Membangun Usaha Sukses sejak Usia Muda. Jakarta: Penerbit Salemba Empat.

Suprayoga, Iswoyo, A., \& Syahrial, R. (2016). Model Pemberdayaan Karang Taruna di Kecamatan Cerme Kabupaten Gresik. Asian Journal of Innovation and Entrepreneurship, 136-147. 